\title{
Theoretical Research on the Separation of Financial Accounting and Tax Accounting
}

\author{
Meihua Xu
}

Liaoning Jianzhu Vocational College, Liaoyang, Liaoning, 111000

Keywords: Financial Accounting, Tax Accounting, Theory

\begin{abstract}
With the further improvement of our fiscal and taxation systems and the reform of accounting, the division of labor between tax accounting and financial accounting will become clearer and clearer. In view of our country's tax law will be more and more sound, tax management is also more stringent, at the same time in order to allow our country in the management of tax revenue and better access to the world, the separation of tax accounting and financial accounting will be an inevitable Claim. This paper analyzes the reasons for the separation of tax accounting and financial accounting and their importance. It also holds that the separation of tax accounting and financial accounting will be the inevitable trend of accounting reform in our country.
\end{abstract}

\section{Introduction}

With the continuous development of China's socialist market economic system, the reform of China's accounting system has achieved fruitful results. The Ministry of Finance has separated tax accounting and financial accounting. Its role is not only limited to the division of these two kinds of accounting. The deeper purpose is to make the work of financial accounting based on clearer execution, accounting and disclosure of information more standardized, reducing the pre-separation accounting not only to meet the accounting In other respects, for the tax department, the tax accounting will be clearer and more practicable in the process of separate tax collection and administration. This article discusses the separation of tax accounting and financial accounting.

\section{Tax accounting and financial accounting}

Tax accounting is a branch of accounting that is gradually produced and developed in the process of the formation and development of financial accounting. At present, in western countries, tax accounting has become independent from financial accounting, forming a set of independent tax accounting system. In our country, tax accounting is still only a part of financial accounting. The adoption of the concept and technology of accounting in the tax law stipulates the interdependence of tax accounting and financial accounting. The process of calculating tax Many methods of accounting simulation, such as the calculation of taxable income similar accounting profit accounting; tax basis is usually taken from the accounting records. It can be said that the tax law is implemented through the technology of accounting, and the same tax management is also adopted accounting methods to maturity. Tax accounting is a product of the common development of accounting and tax law, and financial accounting is the basis, basis and premise of tax accounting. Tax accounting is the record of financial accounting to conduct a reasonable processing and replenishment, the two complement each other to jointly pay taxpayers accounting and supervision,

\section{The difference between tax accounting and financial accounting}

The goal of financial accounting is to calculate the financial affairs of the enterprise according to the accounting standards, at the same time, to provide some relevant information as the stakeholders of the enterprise interests to facilitate their investment decisions. The goal of tax accounting is taxpayers to the tax authorities to provide real tax information to calculate the amount of tax payable in accordance with the law in order to ensure a fair tax, the specific way to achieve tax 
returns.

The legal basis of financial accounting is the financial accounting system and its guidelines, as well as accounting information is true and complete. If the accounting system, accounting standards and the provisions of the tax law in conflict, accounting can be accounted for in accordance with generally accepted accounting principles without taking into account the various requirements of the tax law, until the tax time according to the provisions of the tax law can be adjusted. The basis of tax accounting is the state tax law, accountants because of their own understanding and the special circumstances of the same economic business have different expressions, there will be different accounting results, which is the accounting flexibility and guidelines, the accounting system has Flexible performance.

Financial accounting to generate accrual basis for accounting. The income realized in the current period and the expenses incurred or payable shall be regarded as the current income and expense irrespective of whether the payment is received or paid, and not as the current income and expense. However, tax accounting is based on the realization of payment and accrual basis and the production of accrual basis. The most important manifestation is the caliber of revenue recognition and the standard of cost deduction. The foothold is the state's requirement on fiscal revenue and taxpayers' And realize, do not set up a separate account.

Financial accounting has six elements, namely, profits, equity, liabilities and expenses, income, assets. Their relationship is juxtaposed, that is, the object of accounting are all concrete. The equation for financial accounting is: Assets = Liabilities + Owner's Equity, Revenue - Expenses = Profit. Tax accounting of the four elements, namely, to be deducted items, taxable income, tax liability and taxable income, the equation is: Taxable income - allowable deductions = taxable income, taxable income $\times$ Applicable tax rate $=$ tax payable.

The quality of accounting information, the relevance of the essence of the form, the three principles of prudence is the main separation between financial accounting and tax accounting in the quality of information requirements. The first is the principle of relevance. The financial accounting requirements for the information users, because the accounting information provided by enterprises directly affect the information user's own decision-making and forecasting problems. Tax accounting related requirements for the enterprise tax-related business costs and income ratio between the relationship, the requirements of the costs incurred, fees and other income must be directly related to income, or not allowed to deduct before tax, Such as fine expenses, personal consumption and non-charitable donations and other non-operating expenses. Then there is substance over form principle. Tax accounting interpretation of this principle is more profound than the financial accounting, such as corporate tax avoidance for the business income unreasonable adjustments, tax accounting should be handled reasonably. Finally, the principle of prudence. The principle of prudence is an important principle that financial accounting should follow in dealing with economic business, ie not overvalue assets and earnings, nor underestimate liabilities and expenses. Such as provision for impairment of assets, accrued expenses, to a certain extent, more truly reflect the status of their own businesses and improve the quality of financial accounting information

\section{Tax accounting and financial accounting analysis of the reasons for the separation}

The representative taxpayer of the tax system is the national interest, and its goal is to ensure that enterprises can pay taxes in time. Therefore, the government is more concerned about the issue of corporate income, but the opposite attitude toward the cost. This manifests itself in the extent and standards the government limits on its costs. The goal of financial accounting is to provide the user with a true, fair and objective financial report reflecting the financial status and business of the enterprise. The goal of tax accounting is to ensure the regulation of economic and financial revenue and fair social distribution. Because the goals of the two are different, there is a significant difference between the accounting and taxable benefits, and it is impossible to minimize the difference between the two. The legal basis for financial accounting and tax accounting is different, the former is based on accounting standards, while the latter is based on national tax laws. Both are 
based on different grounds, so the scope of revenue recognition and confirmation of time is different, resulting in accounting income and taxable income have huge differences. In order to separate accounting and reflect this difference, tax accounting should be separate from financial accounting.

In early 2001, in order to achieve coordination with international accounting practices, China promulgated a unified "system of enterprise accounting" based on the experience of reform and established a set of system of enterprise accounting standards that truly and fairly reflected the accounting information of enterprises. Instead of requiring enterprises to carry out accounting, corporate financial accounting has greater flexibility. The Accounting Standards Development Section of the Ministry of Finance drafts the Accounting Standards for Business Enterprises Income Tax (Draft for Comment), recommending the debt law, which shows that the separation of financial accounting and tax accounting is the direction of reform. Since the beginning of the 20th century, tax accounting has been constantly perfected and has been universally valued for the needs of reform and opening up and for its international standardization. Its development has become an important accounting science. Since the implementation of the reform and opening up, more and more foreign-funded enterprises and foreign enterprises have invested in our country, and the amount of investment has also been growing. At the same time, our investment in foreign countries has also increased continuously. In order to meet the tax practice in the world, improve the investment environment, prevent some international tax avoidance, safeguard the interests of enterprises and economic rights and interests of our country, expand our international economic contacts and establish an independent tax accounting system, it is very important.

\section{Tax accounting and the need for separation of financial accounting}

Because of the continuous improvement of China's socialist market economic system, China's accounting system reform has also achieved fruitful results. With the implementation of Accounting Standards for Business Enterprises, the goal of corporate finance and accounting becomes more clear, so only the tax accounting separate from financial accounting, can make financial accounting accounting according to the new accounting standards, so that accounting reform early See results. Only by separating the tax accounting from the financial accounting can the financial accounting be supervised according to the new accounting system and accounting standards.

Under the modern enterprise system, the economic relations between the state and the enterprise are reflected through taxation. In the absence of separate financial accounting and tax accounting, accounting information can not be true and objective to reflect the business or financial conditions. Therefore, the separation of the two is a necessary requirement for establishing a modern enterprise system in our country. This shows that now our country's accounting standards development must absorb the views and suggestions of accounting profession, and must be fully close to the international practice, fully reflect the accounting standards. However, this does not mean that the establishment of the accounting system and the separation of the tax laws are to coordinate the relationship between the two under the precondition of ensuring the relevance of accounting information and the authenticity of accounting information. Enterprises can according to their own characteristics, in the choice of the appropriate choice of the appropriate circumstances for the actual accounting method of business processes.

Starting from the economic level, reflecting the business results and financial conditions, without having to fully comply with the provisions of tax law to implement the accounting business. Also conducive to tax planning business. Corporate tax accounting According to the provisions of tax and production and management features, to plan the mode of operation and tax activities of enterprises so that they not only pay taxes in accordance with the law, but also enjoy the preferential tax to achieve the enterprise to reduce the tax burden, not more tax purposes. Financial accounting has full independence, while not subject to tax laws. Taxpayers' tax matters can be dealt with separately through tax accounting, so that tax accounting can also be independent of financial accounting. Separation Law Because financial accounting to comply with the requirements of generally accepted accounting principles, without the tax laws and regulations, can provide more 
fair accounting information, in order to reflect the financial status of the business and operating results to meet the creditors, shareholders and business management Decision needs. In 2001, when China formally joined the WTO, facing the trend of international coordination of accounting in the context of WTO, the changes in China's accounting system will fully take into account the coordination with international conventions. Therefore, the reform of China's accounting system will also Reflects the separation of the two trends.

\section{Conclusion}

Tax accounting will be gradually separated from the financial accounting of enterprises, not only accounting system and tax reform needs, but also help enterprises to strengthen their own management and construction, urge enterprises to pay attention to tax accounting, accounting information to ensure the quality, at the same time Let our country in the tax administration can better with the international standards, but also accelerated the pace of the accounting discipline. We hope that from the theoretical researches on the separation of tax accounting and financial accounting, we will initiate a more in-depth study on China's financial and accounting reform issues.

\section{References}

[1] Dong Yinghou. Value effect of tax revenue, price effect and cash flow effect [J] .2009 (16)

[2] Tan Chu-ling. Theoretical definition of double taxation of income tax and evading strategy [J] .Zhonghua University of Economics and Law.2008 (06)

[3] Dong Yinghou. The Logical Relationship between Correlation and Reliability of Accounting Information [J] .Journal of Zhengzhou University (Philosophy and Social Science Edition), 2008 (05)

[4] Dong Yinghou. Anti-opportunism rules and its constraints on accounting [J]. Auditing and Economics Research .2008 (05)

[5] Wang Dingding. Institution, personality and tradition [J] IT Manager World. 2008 (14)

[6] Wang Yuanxiao. Bacon practical view [J]. Theory Learning .2008 (06) 